\title{
Bibliography of Personal Names, 1963
}

\section{ELSDON C. SMITH}

\footnotetext{
TT WILL BE APPRECIATED if members will call my attention to items I have missed, and also to items published in 1964, for the next annual installment of this bibliography.
}

Ann or Anne?

in Newsweek, 62.55. July 15, 1963.

New York, 1963.

Short. On the supposed characteristics of people with certain common Christian names.

Appel, John J., "Betzemer": a Nineteenth-Century Cognomen for the Irish

in American Speech, 38.307-08. December, 1963.

New York, 1963.

On this Jewish term for the Irish.

Ashley, L. R. N., French Surnames and the English

in Names, 11.177-81. September, 1963.

Youngstown (Ohio), 1963.

On the French origin of some English surnames.

Beringause, A[rthur] F., Faulkner's Yoknapatawpha Register in Bucknell Review, 11.71-82. May, 1963.

Lewisburg (Pa.), 1963.

On Faulkner's use of personal names.

Blaisdell, Jr., Foster W., Names in the Erex Saga

in Journal of English and Germanic Philology, 62.143-54. January, 1963.

Urbana (Ill.), 1963.

Borkowski, Thomas S., Some Patterns in Polish Surname Changes

in Polish American Studies, 20.14-16. January-June, 1963.

Orchard Lake (Mich.), 1963.

Brender, Myron, Some Hypotheses About the Psychodynamic Significance of Infant Name Selection in Names, 11.1-9. March, 1963.

Youngstown (Ohio), 1963.

On the psychology of name selection by parents. 
Bristol, Lyle O., Jesus in the Gospel of Mark in Religion in Life, 32.429-37. Summer, 1963.

Nashville (Tenn.), 1963.

On the names of Jesus in the Gospel of Mark.

Brzezinski, Jerome A., History of Polish Name Changes in America in Polish American Studies, 20.4-7. January-June, 1963.

Orchard Lake (Mich.), 1963.

Carson, Mother Angela, The Green Knight's Name

in English Language Notes, 1.84-90. December, 1963.

Boulder (Colo.), 1963.

Chaput, Donald C., What Were They Called? Name Changes Since the

Civil War

in Michigan History, 47.335-37. December, 1963.

Lansing (Mich.), 1963.

A comparison of the frequency of Christian names in the Civil War list with the Pontiac telephone list.

Choosing a Name For Baby

Burnham-on-Sea (England), 1962. Pp. 40.

Lists of girls' and boys' names with diminutives and meanings.

Clauson, Gerard, The Name Uygur in Journal of the Royal Asiatic Society, 1963, Parts 3 \& 4, pp. 140-149.

London, 1963.

On Turkish tribal and personal names.

Cross, Jr., Frank Moore, Yahweh and the God of the Patriarchs in The Harvard Theological Review, 55.225-59. October, 1962. Cambridge (Mass.), 1962.

Deatherage, Melvin E., Soviet Surnames, a Handbook Oberamgmerau (Germany), 1962. $333 \mathrm{pp}$.

Duckert, Audrey R., [Nicknames] in Names, 11.74-76. March, 1963.

Youngstown (Ohio), 1963.

On some nicknames of prominent men.

Duckert, Audrey R., Notes and Queries in Names, 11.196-98. September, 1963.

Youngstown (Ohio), 1963.

General, on personal names.

Duncan, R. M., A Note on the Naming of Infants in Names, 11.134-35. June, 1963.

Youngstown (Ohio), 1963.

Fitzmyer, Joseph A., The Name Simon in The Harvard Theological Review, 56.1-5. January, 1963. Cambridge (Mass.), 1963.

On the "change" from Simon to Peter. 
Foreign Versions of English Names

Revised Edition, United States Department of Justice, Immigration and Naturalization Service.

Washington, 1962. pp. [24].

The Bulgarian, French, German, Greek, Hungarian, Italian, Lithuanian, Norwegian, Polish, Rumanian, Russian, Serb and Croatian, Swedish, Ukrainian, Yiddish and Spanish forms of English Christian names.

Fox, J. R., Structure of Personal Names on Tory Island in Man, 63.153-55. October, 1963.

London, 1963.

On Irish names.

Fucilla, Joseph G., New Surnames in the Making in Italy in Orbis, 12.456-62. No. 2, 1963.

Louvain, 1963.

On the names given to foundlings.

Gale, Robert L., Manuel Lujon, Another Name by Willa Cather in Names, 11.210-11. September, 1963.

Youngstown (Ohio), 1963.

On names in literature.

Hersey, William D., The Secret of Remembering Names, Faces and Facts About People

in his How to Cash in on Your Hidden Memory Power, pp. 90-122. Englewood Cliffs (N.J.), 1963.

Hewsen, Robert H., Armenian Names in America in American Speech, 38.214-19. October, 1963.

New York, 1963.

Hille, Arnoldus, OE Seoluini and ON Sjóli

in English Studies, 44.28-35. February, 1963.

Amsterdam, 1963.

On some Old English personal names.

Holman, Winifred Lovering, Masculine Nicknames in The New England Historical and Genealogical Register, 117.175 to 180. July, 1963.

Boston, 1963.

Chiefly lists of pet names with the Christian names to which they belong.

Isaacs, Harold R., A Name to Go by

in his The New World of Negro Americans, pp. 62-71.

New York, 1963.

On names or terms for the Negro race. 
Klymasz, Robert, The Canadianization of Slavic Surnames; A Study in Language Contact

in Names, 11.81 -105, 182-95, 229-53. June, September, December, 1963.

Youngstown (Ohio), 1963.

Kotlarz, Robert J., Writings About the Changing of Polish Names in America

in Polish American Studies, 20.1-4. January-June, 1963.

Orchard Lake (Mich.), 1963.

Kratz, Henry, A Methodological Critique of W. R. Maurer's "Names from The Magic Mountain",

in Names, 11.20.25. March, 1963.

Youngstown (Ohio), 1963.

See Maurer's reply in Names, 11:106.

Lewis, Lionel, S., Kinship Terminology for the American Parent in American Anthropologist, 65.649-52. June, 1963.

Menasha (Wis.), 1963.

Magiera, Stanley A., Some Reasons for First Name Changes in Polish American Studies, 20.8-9. January-June, 1963.

Orchard Lake (Mich.), 1963.

On Polish name changes.

Matthews, C. M., Surnames of Occupation

in History Today, 13.449-58. July, 1963.

London, 1963.

Maurer, Warren R., Another View of Literary Onomastics in Names, 11.106-14. June, 1963.

Youngstown (Ohio), 1963.

Reply to Kratz in Names, 11.20.

Mencken, $\mathrm{H}$ [enry] L[ewis], Proper Names in America in his The American Language (abridged edition by Raven

I. McDavid), Chapter X, pp. 572-701.

New York, 1963.

Name-Droppers

in Newsweek, 62.55. July 8, 1963.

New York, 1963.

On changing of names in Sweden.

Pauls, John P., Names for Characters in Russian Literature in Names, 11.10-19. March, 1963.

Youngstown (Ohio), 1963.

On humorous, meaningful names in Russian literature. 
Pearce, Thomas Matthews, The Lure of Names

in New Mexico Quarterly, 32.160-77. Autumn and Winter, 1962-63.

Albuquerque (N.M.), 1963.

General on personal and place-names.

Qutub, Ishaq Y., Arabic Names and Name Giving

in The Asian Student, 11.5. March 16, 1963.

San Francisco (Calif.), 1963.

Read, William A., Surnames from Southern France

in his Louisiana-French, Chapter IV, pp. 202-219. Revised Edition, [Baton Rouge (La.)], 1963.

Chiefly a reprint of the book first published in 1931.

Ruffner, Frederick G., and Thomas, Robert C., Code Names Dictionary, a Guide to Code Names, Slang, Nicknames, Journalese, and Similar Terms.

Detroit (Mich.), 1963. Pp. 555.

Rule, Lareina, Name Your Baby

New York, 1963. Pp. [viii], 210.

Lists of girls' and boys' names with derivations, meanings and variant forms with names of famous persons who have borne the name, preceded by 21 pages on astrology.

Shannon, Edward, My Troubles with an Irish Name in Catholic Layman, 77.2-6. March, 1963.

New York, 1963.

Smith, Elsdon C., Bibliographia Onomastica 1958-1959. United States. in Onoma, 9.198-206. Numbers 1-2.

Louvain (Belgium), 1962.

Smith, Elsdon C., Bibliography of Personal Names, 1961 [1962]

in Names, 11.128-33. June, 1963.

Youngstown (Ohio), 1963.

Springer, John and Ellen, What To Name Your Baby

New York, 1963. Pp. 128.

Originally published in 1961, under the title, The Catholic Baby Book.

Strzalka, Kenneth M., An Approach to Research in Name Changing in Polish American Studies, 20.7-8. January-June, 1963.

Orchard Lake (Mich.), 1963.

On Polish name changing.

Szajna, Chester B., Some Patterns in Polish First-Name Changes in Polish American Studies, 20.10-12. January-June, 1963. Orchard Lake (Mich.), 1963. 
Taylor, John, Name, Names

in Dictionary of the Bible, Edited by James Hastings, Revised Edition by Frederick C. Grant and H. H. Rowley, pp. 687-88.

New York, 1963.

Trepp, Leo, Jewish Names

in his Eternal Faith, Eternal People, pp. 218-221.

Englewood Cliffs (N.J.), 1962.

Utley, Francis Lee, The Linguistic Component of Onomastics in Names, 11.145-76. September, 1963.

Youngstown (Ohio), 1963.

van den Born, A., Personal Names

in Encyclopedic Dictionary of the Bible, By Louis E. Hartman, col. $1810-1812$.

New York, 1963.

van Imschoot, P., Name

in Encyclopedic Dictionary of the Bible, By Louis E. Hartman, col. $1604-1608$.

New York, 1963.

On names in the Bible including the names of God.

von Feilitzen, Olof, Some Continental Germanic Personal Names in England

in Early English and Norse Studies presented to Hugh Smith in Honour of his Sixtieth Birthday, Edited by Arthur Brown and Peter Foote, pp. 46-61.

London, 1963.

Williams, D. Elwyn, A Short Inquiry into the Surnames in Glamorgan from the Thirteenth to the Eighteenth Centuries

in The Transactions of the Honourable Society of Cymmrodorion, Session 1961, Part II, pp. 45-87.

London, 1962.

Wilson, F. P., "Tom, Dick, and Harry"

in The Times [London] Literary Supplement, No. 3178, January 25, 1963, p. 59.

London, 1963.

A letter on the origin of the phrase.

Zagraniczny, Stanley J., Some Reasons for Polish Surname Changes in Polish American Studies, 20.12-14. January-June, 1963.

Orchard Lake (Mich.), 1963.

On Polish surname changes in America.

Zink, Sidney, The Meaning of Proper Names

in Mind, 72.481 -99. October, 1963.

Edinburgh, 1963.

On the theory of proper names. 